\title{
The Relationship Between The Financial Ratios And Transparency Levels Of Financial Information Disclosures Within The Scope Of Corporate Governance: Evidence From Turkey
}

Burcu Adiloğlu, Ph.D., Istanbul University, Turkey Bengü Vuran, Ph.D., Istanbul University, Turkey

\begin{abstract}
Even though several years have passed since the large corporate scandals of 2001 and 2002, corporate governance continues to remain an area of concern and focus in the global economy, and especially in the emerging markets. Corporate governance refers to the quality, transparency, and dependability of the relationships between the shareholders, board of directors, management, and employees that define the authority and responsibility of each in delivering sustainable value to all the stakeholders. The importance of the issue has been growing at an international level and the quality of corporate governance practices, which is deemed to be as important as financial performance in investment decisions, has become a subject of more serious consideration. In recent years the issue of corporate governance and their impacts on corporate performance have continued to gain widespread prominence in the capital market economy. Higher compliance with the corporate governance standards means more accountable and transparent companies for investors. In this framework, firstly, the transparency levels of financial information disclosures in corporate governance reports and annual reports are calculated by establishing a transparency checklist for the year 2010. MANOVA analysis is conducted to examine the relationship between the calculated transparency levels and financial ratios. The results reveal that transparency level has statistical differences among the group means of return on asset, total debt / total assets, longterm debt / total assets and corporate governance index variables.
\end{abstract}

Keywords: Corporate Governance; Financial Information; Transparency; Financial Ratios; Regression; Turkey

\section{INTRODUCTION}

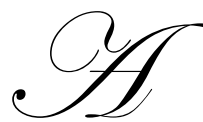

significant feature of the corporate environment during the last two decades has been increasing conformity internationally in the models and mechanisms relied on for corporate governance. (Collier, Zaman, 2000) Corporate governance is the system by which organizations are governed and controlled. It is concerned with the ways in which corporations are governed generally and in particular with the relationship between the management of an organization and its shareholders. In recent years the issue of corporate governance and their impacts on corporate performance have continued to gain widespread prominence in the capital market economy. The expectations of stakeholders with respect to the corporate governance process have never been higher, and scrutiny by regulators and investors never more stringent. Attention has turned to not only the effectiveness of corporate governance but also to transparency and disclosure which is very important for shareholders. 
The impetus for improved transparency and disclosure practices is linked to the broader corporate governance debate both in Europe and on a global basis. The visible corporate governance failures in the US, including Enron, WorldCom and Tyco have found, at least to some extent, European counterparts in the form of Ahold, Cable \& Wireless, and Vivendi Universal. While the impact of these European examples lack the magnitude of those in the US, they nonetheless demonstrate that corporate governance, transparency and control issues are vulnerabilities that are not limited to the US or to emerging market. (Standard \& Poor's, 2003)

Corporate governance refers to the quality, transparency, and dependability of the relationships between the shareholders, board of directors, management, and employees that define the authority and responsibility of each in delivering sustainable value to all the stakeholders. Transparency is clearly linked to the debate about governance reform, as it embodies one of the core principles corporate governance. It is presented as an overarching cornerstone of the OECD corporate governance guidelines: "Investor confidence and market efficiency depend on the disclosure of accurate timely information about corporate performance. To be of value in the global capital markets, disclosed information should be clear, consistent and comparable" (OECD,1998) Transparency and Disclosure (T\&D) are fundamental components of corporate governance. Greater transparency and disclosure keep corporate stakeholders beter informed about the way a company is being managed and governed. (Healy \& Palepu, 2001.)

Many countries have since introduced voluntary codes endorsing the OECD principles. The universal principles of corporate governance are fairness, accountability, transparency and responsibility. The Principles consist of four main sections namely shareholders, disclosure and transparency, stakeholders and board of directors (CMB, 2003);

The second section of OECD Corporate Governance Principles discusses the Principles regarding disclosure and transparency issues. Within this scope, Principles for establishment of information policies in companies with respect to shareholders and the adherence of companies to these policies are discussed. The conditions of today's global financial economy and conditions faced in our country have been taken into consideration while setting single standards for the procedures for providing information via periodic financial statements and reports and detailing such standards through consideration of functionality. (CMB, 2003);

In Turkey, the corporate governance framework rests primarily upon a "public enforcement" model, with the Capital Markets Board (CMB) playing a leading role in setting corporate governance standards for publicly held companies, enforcing the applicable standards and fostering market integrity. The ambitious, state-of-the-art and comprehensive CMB principles, adopted in 2003, are the principal source of non-binding corporate governance standards for publicly held companies. They were revised in 2005 to take into account revisions made to the OECD Principles in 2004. Listed companies must publish an annual Corporate Governance Compliance statement, disclosing which CMB principles have not been adopted and the reasons for not doing so. (CMB, 2003);

The corporate environment in Turkey, however, is better positioned than many European countries to tackle corporate governance challenges ahead, because: (OECD, 2006,)

- the authorities have already adopted, or are introducing, high quality corporate governance standards (including audit standards);

- $\quad$ transparency has improved significantly, particularly in the are of financial reporting (listed companies are urged to adopt accounting standards which are almost identical to IFRS);

- a positive trend toward widespread implementation of a number of key corporate governance standards can be observed; and

- the authorities are now focusing their attention on monitoring implementation, identifying the remaining gaps and risk areas, focusing their resources on these risk areas and implementing institutional reforms as needed to strengthen supervisory, enforcement and remedial processes.

The rest of the paper is organized as follows: Section II provides a detailed survey of past studies. Section III explains the data (variables employed) and methodology while the results are presented in Section IV. Finally, Section V gives the conclusion. 


\section{LITERATURE REVIEW}

Several studies have been and is still being realized in the area of corporate governance. Healy\& Palepu (2001) suggest that better disclosure has a positive impact on the efficient functioning of capital markets. Brown and Caylor $(2006 \mathrm{a}, 2006 \mathrm{~b})$ construct a governance score using ISS governance factors and find that firms with lower governance scores have higher return on equity, higher profit margins, and higher firm valuations. Using principal components analysis, Larcker, Richardson, and Tuna (2007) construct 14 governance factors and find that these are related to future operating performance and stock returns.

Klapper and Love's (2002) empirical study provides evidence that firm-level corporate governance quality matter more in countries with weak legal environments in attracting investors. This finding suggests that wellgoverned firms can compensate for weak legal/institutional environment and law enforcement at the national level by establishing good governance practices such as greater firm disclosure and stronger minority shareholder rights at the company level.

Aras and Crowther (2008a, b, c) stated that the aim of the corporate governance principles is to "increase both shareholder value and the satisfaction of other stakeholders". Achievement of this aim is largely linked with the development of capital markets in which the corporate governance principles - transparency, accountability, responsibility and fairness - are understood by both investors and shareholders.

Full disclosure and transparency of financial information are vital components of the Corporate Governance Framework (OECD, 1999) and are regarded as important indicators of Corporate Governance quality. Beeks and Brown (2005) find that firms with higher Corporate Governace quality make more informative disclosures. Sadka (2004) provides theoretical and empirical evidence that the public sharing of financial and analyst reports have enhanced factor productivity and economic growth in 30 countries. Berglof and Pajuste (2005) report that more information is publicly available in larger firms, firms with lower leverage, higher financial performance, higher market-to-book ratios and more concentrated ownership. several studies have done which investigates the relationship between disclosure and leverage. For e.g.,while Dellas and Hess (2005) found significant relationship between disclosure and leverage, Ho and Wong (2001) found no relationship between disclosure and leverage.

Sandeep et al. (2002) use a new dataset to analyze Transparency \& Disclosure scores (T\&D score) in 19 emerging markets for 354 firms representing 70\% of S\&P/IFCI Index market capitalization over the 3 years ending in 2000. They analyze differences across countries, economic sectors and trend over the 3 years. They find that the Asian emerging markets and South Africa have significantly higher transparency and disclosure compared to the Latin American, Eastern European, and Middle Eastern emerging markets. The gap between the Asian emerging markets and South Africa over other emerging markets has increased over the last 3 years. They do not find any significant differences in T\&D scores among economic sectors. Changes in the T\&D scores over the last 3 years, however, differ by economic sectors for the 6 markets with the largest investable market capitalization and/or number of observations, viz. Brazil, Poland, South Africa, India, Thailand, and Korea. They then study the relationships between T\&D scores and cross-holdings for the 6 emerging markets. For the 6 markets except Korea, correlation between cross-holdings and T\&D scores is negative. For the 6 markets except South Africa, correlation between price-to-book ratios and T\&D scores is positive.

Aksu and Kösedağ (2006) use $98 \mathrm{~T} \& \mathrm{D}$ attributes they used in and their classification of the attributes into three categories: ownership structure and investor relations, financial transparency and information disclosure, and board and management structures and processes. They evaluate the T\&D practices of the 52 largest and most liquid firms in the Istanbul Stock Exchange (ISE), based on their English and local language annual reports and websites. They also consider a simple model that sequentially links agency problems to CG/T\&D mechanisms in place, which in turn impact firm-level and economy-wide financial performance. Concentrating on the causal side of the model the determinants of $T \& D$ scores - they provide out-of-sample evidence that firm size, financial performance and market-to-book equity best explain the variation in T\&D scores in the ISE. 


\section{DATA \&RESEARCH METHODOLOGY}

This study investigates the relationship between the transparency level and the financial performance indicators of firms operating in real sector. Our sample only consists of the 57 largest manufacturing companies which are listed in ISE 100 indice during the year 2010. The distribution and percentage of 57 companies by sectors are shown in Figure 1 and Figure 2.

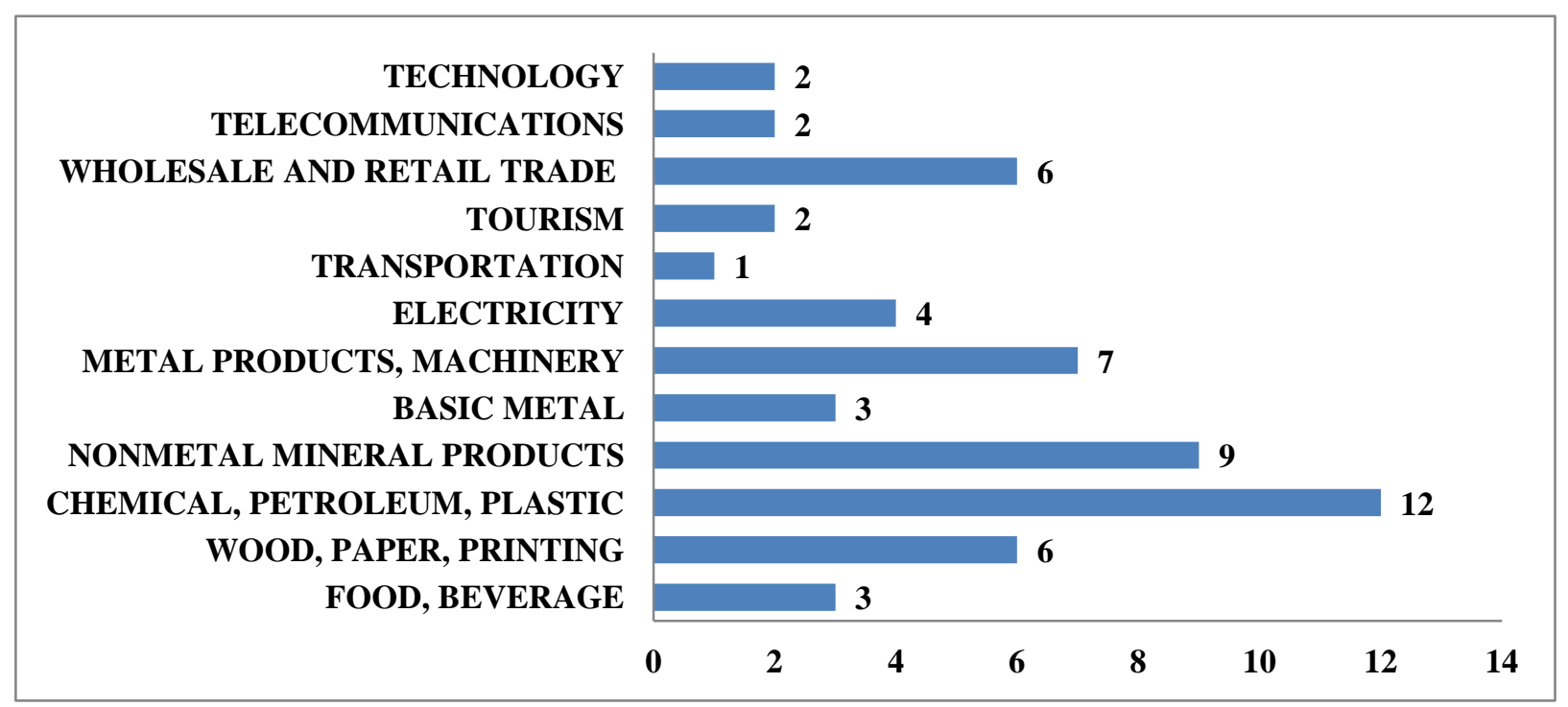

Figure 1: Number of companies by sectors

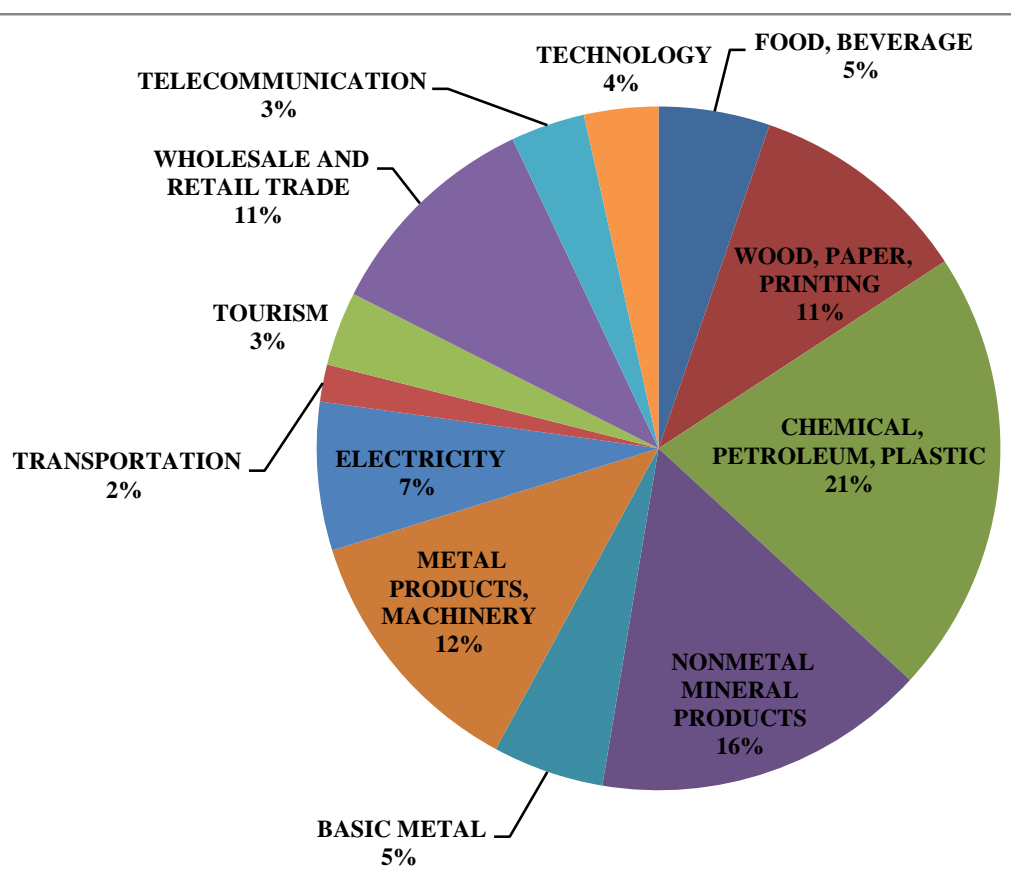

Figure 2: Percentage of companies by sectors 
The study analyzes disclosure practices of these firms from an investor perspective. It therefore focuses on sources of information that are most readily accessible by local and international investors - typically the latest available English language and local language company annual reports and the English and Turkish web sites. In this framework, the transparency levels of financial information disclosures in corporate governance reports and annual reports are calculated by establishing a transparency checklist. In the transparency checklist, 27 criteria derived from only the disclosure and transparency section of the OECD Corporate Governance Principles. (See Appendix 1) The financial statements are gathered from ISE web site and the governance compliance and annual reports are taken from web sites of firms investigated.14 financial ratios (calculated as financial performance indicators) and 1 dummy variable (Corporate Governance Index), totally 15 independent variables are shown in Table 1.

Table 1: Financial Performance Indicators Used in the Study

\begin{tabular}{|l|l|c|}
\hline \multicolumn{1}{|c|}{ Financial Ratios } & \multicolumn{1}{c|}{ Calculation } & Used in Analysis as \\
\hline Current Ratio & Curret Assets / Current Liabilities & $\mathbf{X}_{\mathbf{1}}$ \\
\hline Acid-test Ratio & Curret Assets- Inventories / Current Liabilities & $\mathbf{X}_{\mathbf{2}}$ \\
\hline Cash Ratio & Cash \& Bank / Current Liabilities & $\mathbf{X}_{\mathbf{3}}$ \\
\hline Net Profit Margin & Net Profit / Sales & $\mathbf{X}_{\mathbf{4}}$ \\
\hline Gross Profit Margin & Gross Profit / Sales & $\mathbf{X}_{\mathbf{5}}$ \\
\hline Operating Margin & EBIT / Sales & $\mathbf{X}_{\mathbf{6}}$ \\
\hline Return on Equity & Net Profit / Equity & $\mathbf{X}_{\mathbf{7}}$ \\
\hline Return on Asset & Net Profit / Total Assets & $\mathbf{X}_{\mathbf{8}}$ \\
\hline Debt Ratio & Total Debt / Total Assets & $\mathbf{X}_{\mathbf{9}}$ \\
\hline Short-term Debt Ratio & Short-term Debt / Total Assets & $\mathbf{X}_{\mathbf{1 0}}$ \\
\hline Long-term Debt Ratio & Long-term Debt / Total Assets & $\mathbf{X}_{\mathbf{1 1}}$ \\
\hline Fixed-Asset Turnover Ratio & Sales / Fixed Assets & $\mathbf{X}_{\mathbf{1 2}}$ \\
\hline Ability to Pay Interest & Cash From Operating Activities / Interest Expense & $\mathbf{X}_{\mathbf{1 3}}$ \\
\hline Earning Per Share & Net Income / Number of Common Stock & $\mathbf{X}_{\mathbf{1 4}}$ \\
\hline Corporate Governance Index & $\mathbf{X}_{\mathbf{1 5}}$ \\
\hline
\end{tabular}

When the relevant information in the annual report and corporate governance compliance report is found, "1" is assigned to the company. Otherwise, the company gets " 0 " point. The points for each company are summed up and the transparency score is calculated by dividing this sum to 27. After calculating this transparency level score of 57 companies, these companies are divided into 3 categories as shown in Table 2 and MANOVA Analysis is applied to investigate if there is a significant difference between means of at least one financial ratio of at least two groups of transparency categories.

Table 2: Category Diversification of Firms

\begin{tabular}{|c|l|c|c|}
\hline Category & Name of the categories & Transparency Level & Number of Companies \\
\hline 1 & Most Transparent & $85 \%-100 \%$ & 23 \\
\hline 2 & Transparent & $84 \%-70 \%$ & 27 \\
\hline 3 & Least Transparent & $69 \%$-below & 7 \\
\hline
\end{tabular}

MANOVA (Multivariate Analysis of Variance) is employed by SPSS 17 in order to assess group differences across the financial ratios simultaneously. The MANOVA (multivariate analysis of variance) is an extension of analysis of variance to accommodate more than one dependent variable. It is a dependence technique that measures the differences for two or more metric dependent variables based on a set of categorical (nonmetric)

\footnotetext{
${ }^{1}$ The board meeting of ISE on 23 February 2005 it was decided that a corporate governance index be established for listed companies. ISE Corporate Governance Index (XKURY) is the index in which companies applying Corporate Governance Principles are included. ISE Corporate Governance Index aims to measure the price and return performances of ISE-listed companies. In Turkey, there are 30 companies listed in Corporate Governance Index (XKURY) as of June, $30,2011$. (www.ise.gov.tr)
}

(C) 2012 The Clute Institute http://www.cluteinstitute.com/ 
variables acting as independent variables. Manova analysis is applied in four steps: (1) multivariate tests: to test the basic assumption of Manova, (2) Levene's Test of Equality of Error Variances: to test for equality of error variances across dependent variables, (3) Test of Between-Subjects Effect: to investigate if the independent variable differ on all of the dependent measures, (4) Post hoc tests: to test the significance of differences in levels of an independent factor with respect to a dependent variables.

\section{EMPIRICAL FINDINGS}

Table 3: Multivariate Tests

\begin{tabular}{|c|c|c|c|c|c|c|c|}
\hline \multicolumn{2}{|l|}{ Effect } & Value & $\mathbf{F}$ & $\begin{array}{c}\text { Hypothesis } \\
\text { df }\end{array}$ & $\begin{array}{c}\text { Error } \\
\text { df }\end{array}$ & Sig. & $\begin{array}{c}\text { Partial Eta } \\
\text { Squared }\end{array}$ \\
\hline \multirow[t]{4}{*}{ Intercept } & \begin{tabular}{|l|} 
Pillai's Trace \\
\end{tabular} & 0,9659 & 82,9427 & 14 & 41 & 0,000 & 0,9659 \\
\hline & Wilks' Lambda & 0,0341 & 82,9427 & 14 & 41 & 0,000 & 0,9659 \\
\hline & Hotelling's Trace & 28,3219 & 82,9427 & 14 & 41 & 0,000 & 0,9659 \\
\hline & Roy's Largest Root & 28,3219 & 82,9427 & 14 & 41 & 0,000 & 0,9659 \\
\hline Transparency & Pillai's Trace & 0,7052 & 1,6338 & 28 & 84 & 0,0451 & 0,3526 \\
\hline \multirow[t]{3}{*}{ Category } & Wilks' Lambda & 0,3977 & 1,7156 & 28 & 82 & 0,0317 & 0,3694 \\
\hline & Hotelling's Trace & 1,2562 & 1,7946 & 28 & 80 & 0,0226 & 0,3858 \\
\hline & \begin{tabular}{|l} 
Roy's Largest Root \\
\end{tabular} & 0,9968 & 2,9905 & 14 & 42 & 0,0030 & 0,4992 \\
\hline
\end{tabular}

Table 3 contains the four most commonly used multivariate tests (Pillai's Trace, Wilk's Lambda, Hotelling's Trace and Roy's Largest Root) and the basic hypothesis of Manova (the population means on the multiple dependent variables are equal across groups) is tested by the multivariate tests. All of the statistical criteria provide similar conclusions. Since the significance level of all tests are smaller than $5 \%$, each of the four measures indicate that there is a significant difference between the means of at least one dependent variable (financial ratio) of at least two groups of independent variable (transparency levels of firms).

Table 4: Levene's Test of Equality of Error Variances

\begin{tabular}{|l|c|c|c|c|}
\hline & $\mathbf{F}$ & $\mathbf{d f 1}$ & $\mathbf{d f 2}$ & Sig. \\
\hline $\mathbf{X}_{\mathbf{1}}$ &, 253 & 2 & 54 &, 777 \\
\hline $\mathbf{X}_{\mathbf{2}}$ &, 816 & 2 & 54 &, 448 \\
\hline $\mathbf{X}_{\mathbf{3}}$ & 3,074 & 2 & 54 &, 054 \\
\hline $\mathbf{X}_{\mathbf{4}}$ & 2,211 & 2 & 54 &, 119 \\
\hline $\mathbf{X}_{\mathbf{5}}$ & 1,610 & 2 & 54 &, 209 \\
\hline $\mathbf{X}_{\mathbf{6}}$ & 3,668 & 2 & 54 &, 032 \\
\hline $\mathbf{X}_{\mathbf{7}}$ & 1,414 & 2 & 54 &, 252 \\
\hline $\mathbf{X}_{\mathbf{8}}$ & 11,406 & 2 & 54 &, 000 \\
\hline $\mathbf{X}_{\mathbf{9}}$ &, 161 & 2 & 54 &, 852 \\
\hline $\mathbf{X}_{\mathbf{1 0}}$ & 2,450 & 2 & 54 &, 096 \\
\hline $\mathbf{X}_{\mathbf{1 1}}$ & 4,087 & 2 & 54 &, 022 \\
\hline $\mathbf{X}_{\mathbf{1 2}}$ & 1,671 & 2 & 54 &, 198 \\
\hline $\mathbf{X}_{\mathbf{1 3}}$ &, 762 & 2 & 54 &, 472 \\
\hline $\mathbf{X}_{\mathbf{1 4}}$ & 1,779 & 2 & 54 &, 179 \\
\hline $\mathbf{X}_{\mathbf{1 5}}$ & 930,526 & 2 & 54 &, 000 \\
\hline
\end{tabular}

Table 4 displays the results of Levene's test for equality of error variances across financial ratios. As it is seen in the table, it can be concluded that equal variances is assumed for variables with significance level $>0,05$.

After significant results are obtained by multivariate tests, for further investigation the test of betweensubjects effect is performed in relation to each of the dependent variables ( financial ratios). The Test of BetweenSubjects Effects investigates if there is a significant difference between the means of at least one financial ratio of at least two groups of the transparency levels. In Table 5, each of the dependent variables is listed with their associated univariate F, df and Sig. values. The results confirm that the type of transparency levels reveal the differences across the financial ratios namely $\mathrm{X}_{8}, \mathrm{X}_{11}, \mathrm{X}_{15}$ for $5 \%$ significance level and $\mathrm{X}_{9}$ for $10 \%$ significance level. 
Table 5: Test of Between-Subjects Effect Table

\begin{tabular}{|c|c|c|c|c|c|c|c|}
\hline Source & Dependent Variable & Type III Sum of Squares & df & Mean Square & $\mathbf{F}$ & Sig. & Partial Eta Squared \\
\hline Transparency & $\mathbf{X}_{1}$ & 2,9581 & 2 & 1,4791 & 0,4044 & 0,6694 & 0,0148 \\
\hline \multirow[t]{14}{*}{ Category } & $\mathbf{X}_{2}$ & 4,4336 & 2 & 2,2168 & 0,6010 & 0,5519 & 0,0218 \\
\hline & $\mathbf{X}_{3}$ & 1,8179 & 2 & 0,9089 & 0,7750 & 0,4658 & 0,0279 \\
\hline & $\mathbf{X}_{4}$ & 0,3139 & 2 & 0,1569 & 1,2985 & 0,2813 & 0,0459 \\
\hline & $X_{5}$ & 0,0146 & 2 & 0,0073 & 0,1454 & 0,8650 & 0,0054 \\
\hline & $\mathbf{X}_{6}$ & 0,1222 & 2 & 0,0611 & 1,9957 & 0,1458 & 0,0688 \\
\hline & $\mathbf{X}_{7}$ & 0,1478 & 2 & 0,0739 & 2,2995 & 0,1101 & 0,0785 \\
\hline & $\mathbf{X}_{8}$ & 0,0757 & 2 & 0,0379 & 3,6182 & 0,0335 & 0,1182 \\
\hline & $\mathbf{X}_{9}$ & 0,2608 & 2 & 0,1304 & 2,8005 & 0,0696 & 0,0940 \\
\hline & $\mathbf{X}_{10}$ & 0,0538 & 2 & 0,0269 & 0,8672 & 0,4259 & 0,0311 \\
\hline & $X_{11}$ & 0,1865 & 2 & 0,0933 & 5,7181 & 0,0056 & 0,1748 \\
\hline & $X_{12}$ & 1150,0449 & 2 & 575,0224 & 0,4537 & 0,6377 & 0,0165 \\
\hline & $\mathbf{X}_{13}$ & 48,1736 & 2 & 24,0868 & 0,1090 & 0,8969 & 0,0040 \\
\hline & $X_{14}$ & 13,7041 & 2 & 6,8521 & 1,8839 & 0,1619 & 0,0652 \\
\hline & $X_{15}$ & 2,5934 & 2 & 1,2967 & 12,3887 & 0,0000 & 0,3145 \\
\hline
\end{tabular}


Table 6: Post hoc tests for significant dependent variables

\begin{tabular}{|c|c|c|c|c|c|c|c|c|}
\hline \multirow[t]{2}{*}{\begin{tabular}{|l|} 
Dependent Variable \\
\end{tabular}} & & (I) code & $(J)$ code & Mean Difference (I-J) & Std. Error & Sig. & 95\% Confidence Interval & \\
\hline & & & & & & & Lower Bound & Upper Bound \\
\hline \multirow[t]{12}{*}{$\mathbf{X}_{8}$} & Tukey HSD & 1 & 2 & $-0,0421$ & 0,0218 & 0,1700 & $-0,0963$ & 0,0121 \\
\hline & & & 3 & $-0,1163$ & 0,0794 & 0,4713 & $-0,3721$ & 0,1396 \\
\hline & & 2 & 1 & 0,0421 & 0,0218 & 0,1700 & $-0,0121$ & 0,0963 \\
\hline & & & 3 & $-0,0741$ & 0,0806 & 0,7727 & $-0,3290$ & 0,1807 \\
\hline & & 3 & 1 & 0,1163 & 0,0794 & 0,4713 & $-0,1396$ & 0,3721 \\
\hline & & & 2 & 0,0741 & 0,0806 & 0,7727 & $-0,1807$ & 0,3290 \\
\hline & Tamhane & 1 & 2 & $-0,0421$ & 0,0290 & 0,3226 & $-0,1121$ & 0,0278 \\
\hline & & & 3 & $-0,1163$ & 0,0442 & 0,0292 & $-0,2227$ & $-0,0098$ \\
\hline & & 2 & 1 & 0,0421 & 0,0290 & 0,3226 & $-0,0278$ & 0,1121 \\
\hline & & & 3 & $-0,0741$ & 0,0434 & 0,2112 & $-0,1787$ & 0,0304 \\
\hline & & 3 & 1 & 0,1163 & 0,0442 & 0,0292 & 0,0098 & 0,2227 \\
\hline & & & 2 & 0,0741 & 0,0434 & 0,2112 & $-0,0304$ & 0,1787 \\
\hline \multirow[t]{12}{*}{$\mathbf{X}_{9}$} & Tukey HSD & 1 & 2 & 0,1390 & 0,0612 & 0,0687 & $-0,0085$ & 0,2866 \\
\hline & & & 3 & 0,1333 & 0,0931 & 0,3326 & $-0,0912$ & 0,3577 \\
\hline & & 2 & 1 & $-0,1390$ & 0,0612 & 0,0687 & $-0,2866$ & 0,0085 \\
\hline & & & 3 & $-0,0058$ & 0,0915 & 0,9978 & $-0,2263$ & 0,2148 \\
\hline & & 3 & 1 & $-0,1333$ & 0,0931 & 0,3326 & $-0,3577$ & 0,0912 \\
\hline & & & 2 & 0,0058 & 0,0915 & 0,9978 & $-0,2148$ & 0,2263 \\
\hline & Tamhane & 1 & 2 & 0,1390 & 0,0611 & 0,0802 & $-0,0122$ & 0,2903 \\
\hline & & & 3 & 0,1333 & 0,0933 & 0,4571 & $-0,1345$ & 0,4010 \\
\hline & & 2 & 1 & $-0,1390$ & 0,0611 & 0,0802 & $-0,2903$ & 0,0122 \\
\hline & & & 3 & $-0,0058$ & 0,0921 & 0,9999 & $-0,2725$ & 0,2609 \\
\hline & & 3 & 1 & $-0,1333$ & 0,0933 & 0,4571 & $-0,4010$ & 0,1345 \\
\hline & & & 2 & 0,0058 & 0,0921 & 0,9999 & $-0,2609$ & 0,2725 \\
\hline
\end{tabular}


Table 6: Post hoc tests (Continued)

\begin{tabular}{|c|c|c|c|c|c|c|c|c|}
\hline \multirow{2}{*}{ Dependent Variable } & & (I) code & (J) code & Mean Difference (I-J) & Std. Error & Sig. & 95\% Confidence Interval & \\
\hline & & & & & & & Lower Bound & Upper Bound \\
\hline \multirow{12}{*}{$X_{11}$} & Tukey HSD & 1 & 2 & 0,1205 & 0,0362 & 0,0045 & 0,0332 & 0,2078 \\
\hline & & & 3 & 0,0335 & 0,0551 & 0,8170 & $-0,0994$ & 0,1663 \\
\hline & & 2 & 1 & $-0,1205$ & 0,0362 & 0,0045 & $-0,2078$ & $-0,0332$ \\
\hline & & & 3 & $-0,0871$ & 0,0542 & 0,2513 & $-0,2176$ & 0,0435 \\
\hline & & 3 & 1 & $-0,0335$ & 0,0551 & 0,8170 & $-0,1663$ & 0,0994 \\
\hline & & & 2 & 0,0871 & 0,0542 & 0,2513 & $-0,0435$ & 0,2176 \\
\hline & Tamhane & 1 & 2 & 0,1205 & 0,0374 & 0,0088 & 0,0263 & 0,2147 \\
\hline & & & 3 & 0,0335 & 0,0643 & 0,9420 & $-0,1470$ & 0,2139 \\
\hline & & 2 & 1 & $-0,1205$ & 0,0374 & 0,0088 & $-0,2147$ & $-0,0263$ \\
\hline & & & 3 & $-0,0871$ & 0,0569 & 0,4269 & $-0,2639$ & 0,0898 \\
\hline & & 3 & 1 & $-0,0335$ & 0,0643 & 0,9420 & $-0,2139$ & 0,1470 \\
\hline & & & 2 & 0,0871 & 0,0569 & 0,4269 & $-0,0898$ & 0,2639 \\
\hline \multirow[t]{12}{*}{$\mathbf{X}_{15}$} & Tukey HSD & 1 & 2 & 0,4348 & 0,0918 & 0,0000 & 0,2135 & 0,6560 \\
\hline & & & 3 & 0,4348 & 0,1397 & 0,0082 & 0,0982 & 0,7714 \\
\hline & & 2 & 1 & $-0,4348$ & 0,0918 & 0,0000 & $-0,6560$ & $-0,2135$ \\
\hline & & & 3 & 0,0000 & 0,1372 & 1,0000 & $-0,3307$ & 0,3307 \\
\hline & & 3 & 1 & $-0,4348$ & 0,1397 & 0,0082 & $-0,7714$ & $-0,0982$ \\
\hline & & & 2 & 0,0000 & 0,1372 & 1,0000 & $-0,3307$ & 0,3307 \\
\hline & Tamhane & 1 & 2 & 0,4348 & 0,1057 & 0,0014 & 0,1617 & 0,7078 \\
\hline & & & 3 & 0,4348 & 0,1057 & 0,0014 & 0,1617 & 0,7078 \\
\hline & & 2 & 1 & $-0,4348$ & 0,1057 & 0,0014 & $-0,7078$ & $-0,1617$ \\
\hline & & & 3 & 0,0000 & 0,0000 & $\dot{\square}$ & 0,0000 & 0,0000 \\
\hline & & 3 & 1 & $-0,4348$ & 0,1057 & 0,0014 & $-0,7078$ & $-0,1617$ \\
\hline & & & 2 & 0,0000 & 0,0000 & -1 & 0,0000 & 0,0000 \\
\hline
\end{tabular}


For each dependent variable, post hoc test displays that if there is a significant difference between the group means of independent variable. This helps to specify the exact nature of the overall effect determined by the multivariate test. Post hoc methods are widely used because of the ease in which multiple comparisons are made. The most common post hoc procedures are Tukey's honestly significant difference test, applied when equality of error variances is assumed, and Tamhane's T2 test applied in case of inequality of error variances.

In Table 6 the transparency level does differ in relation to $\mathrm{X}_{8}, \mathrm{X}_{9}, \mathrm{X}_{11}$ and $\mathrm{X}_{15}$ variables. As it is seen in Levene Test Table, while the error variances of $X_{9}$ are equal, $X_{8}, X_{11}$ and $X_{15}$ 's are not. Therefore, for variable $X_{9}$ Tukey Test, for variables $\mathrm{X}_{8}, \mathrm{X}_{11}$ and $\mathrm{X}_{15}$ Tamhane test are considered. For $\mathrm{X}_{8}$ there is a significant difference between first and third category for $5 \%$ significance level, for $\mathrm{X}_{9}$ there is a significant difference between first and second category for $10 \%$ significance level, for $\mathrm{X}_{11}$ there is a significant difference between first and second category for $5 \%$ significance level, for $\mathrm{X}_{15}$ there is a significant difference between first and second, first and third categories for $1 \%$ significance level.

\section{CONCLUSION}

Within the past decade, the concept of corporate governance has played an ever increasingly significant role in enhancing the competitive power of global financial markets. An important branch in this literature brings together comparisons of financial and legal systems, a branch for which increasingly the term "corporate governance" is used. One of the most important underlying factors behind the cause of both the recent financial crises and recent company scandals that broke out across the world can be attributed to the inadequacy of sound Corporate Governance Principles by both the public and private sectors. As a result, the concept of corporate governance has gained increased attention from all around the world. Transparency and disclosure are fundamental components of corporate governance. Transparency defined as, sharing information and acting in an open manner and transparency allows stakeholders to gather information that may be critical to uncovering abuses and defending their interests Transparent systems have clear procedures for public decision-making and open channels of communication between stakeholders and officials, and make a wide range of information. Greater transparency and disclosure keep corporate stakeholders better informed about the way a company being managed and governed.

The aim of the study is to investigate the relationship between the transparency level and the financial performance indicators of 57 firms operating in real sector in ISE-100 index during the year 2010. Firstly, the transparency levels of financial information disclosures in corporate governance reports and annual reports are calculated by establishing a transparency checklist for the year 2010. After calculating this transparency level score of 57 companies, these companies are divided into 3 categories. MANOVA analysis is applied to test the relationship between the transparency level and the financial performance indicators. The results reveal that transparency level has statistically significant effect between the group means of three variables. These variables are namely return on asset, total debt / total assets, long-term debt / total assets and corporate governance index.

- $\quad$ For Return on asset variable $\left(X_{8}\right)$; there is a significant difference between first and second category for 5 $\%$ significance level. The mean of the first group is greater than the second one.

- $\quad$ For Total debt / Total Asset ratio variable $\left(\mathrm{X}_{9}\right)$; there is a significant difference between first and second category for $10 \%$ significance level. The mean of the first group is greater than the second one.

- $\quad$ For long-term debt / total assets ratio variable $\left(\mathrm{X}_{11}\right)$; there is a significant difference between first and second category for $5 \%$ significance level. The mean of the first group is greater than the second one.

- For corporate governance index variable $\left(\mathrm{X}_{15}\right)$, there is a significant difference between first and second, first and third categories for $1 \%$ significance level. This means that if the company is listed in ISE corporate governance index, it is likely to be more transparent.

For further studies coefficients can be assigned to criteria in transparency checklist in relation to importance of the subject. In this study, only the financial information disclosure transparency is investigated. It can be also generalized for all corporate governance issues. And to gain more financial information disclosure for Turkish market, all companies listed in ISE can be added to population of the study. 


\section{AUTHOR INFORMATION}

Burcu Adiloğlu, Ph.D., Research and Teaching Assistant, Istanbul University, School of Business, Department of Accounting, Turkey. E-mail: adiloglu@ @istanbul.edu.tr. Corresponding author.

Bengü Vuran, Ph.D., Research and Teaching Assistant, Istanbul University, School of Business, Department of Finance, Turkey. E-mail: benguv@istanbul.edu.tr

\section{REFERENCES}

1. Aksu,M., Kösedağ,A., (2006), Transparency and Disclosure Scores and their Determinants in the Istanbul Stock Exchange. Corporate Governance: An International Review, 14: 277-296.

2. Aras, G. and Crowther, D. (2008a), "Governance and sustainability: an investigation into the relationship between corporate governance and corporate sustainability", Management Decision, Vol. 46 No. 3.

3. Aras, G. and Crowther, D. (2008b), "Exploring frameworks of corporate governance", in Aras, G. And Crowther, D. (Eds), Culture and Corporate Governance, SRRNet, Leicester, pp. 3-16.

4. Aras, G. and Crowther, D. (2008c), "The future of corporate governance: a prognosis", in Aras, G. And Crowther, D. (Eds), Culture and Corporate Governance, SRRNet, Leicester, pp. 223-36.

5. Beeks, W. and Brown, P. (2005) Do Better Governed Australian Firms Make More Informative Disclosures. Working paper,LancasterUniversity

6. Berglof, E. and Pajuste, A. (2005) What Do Firms Disclose and Why? Enforcing Corporate Governance and Transparency in Central and Eastern Europe. Working paper, Stockholm School of Economics.

7. $\quad$ Capital Markets Board. (2003, June). Corporate governance principles.

8. Collier, P, Zaman,M., Convergence in European Governance Codes:The Audit Committee Concept, School of Business and Economics, Streatham Court, Rennes Drive, University of Exeter, Paper Number 04/01, ISSN 14732904

9. Dellas, H. and Hess, M. (2005) Financial Development and Stock Returns: A Cross-Country Analysis, Journal of International Money and Finance, 24, 891-912.

10. Hair, J., Black, B.,Babin, B., Anderson,R.E., Tatham,R., Multivariate Data Analysis (6th Edition), Prentice Hall, 2005.

11. Healy, P. M., \& Palepu, K. G. (2001.). Information Asymmetry, Corporate Disclosure and the Capital Markets: A Review of the Empirical Disclosure Literature. Journal of Accounting \& Economics, Vol. 31, No. 1-3, Sept. .

12. Ho, S. and Wong, K. S. (2001) A Study of the Relationship Between Corporate Governance Structures and the Extent of Voluntary Disclosures, Journal of International Accounting, Auditing and Taxation, 10, 139156

13. Klapper, L.F. and Love, I. (2002), "Corporate governance, investor protection and performance in emerging markets", World Bank Policy Research Working Paper, No. 2818, Washington, DC.

14. Larcker, D., Richardson, S., and Tuna, I., 2007, "Corporate Governance, Accounting Outcomes, and Organizational Performance,” The Accounting Review 82, 963-1008.

15. OECD, Business Sector Advisory Group on Corporate Governance, "Corporate Governance: Improving Competitiveness and Access to Capital in Global Markets", 1998.

16. OECD. (1999). OECD principles of corporate governance.

17. OECD. (2006). Corporate governance in Turkey: A pilot study.

18. Sadka, G. (2004) Financial Reporting, Growth, and Productivity: Theory and International Evidence. Working paper, University of Chicago.

19. Sandeep A. Patel', Amra Balic and Liliane Bwakira (2002)Measuring transparency and disclosure at firmlevel in emerging markets, Emerging Markets Review Volume 3, Issue 4, 1 December 2002, Pages 325-337

20. Standard \& Poor's (2003), Transparency and Disclosure Study, April. 


\section{APPENDIX 1: Financial Information Transparency Check-List}

1. Annual reports including periodical financial statements and the audit report are available in company's web site.

2. Corporate governance compliance reports are available in company's web site.

3. Periodical financial statements and footnotes prepared in accordance with the international accounting standards and applied accounting policies are included in the footnotes of the financial statements.

4. The footnotes of the periodical financial statements include all off-balance sheet transactions including contingent claims, all liabilities and operational results that would affect future financial status, liquidity of the company, investment expenditures, investment sources, all factors that would affect the future relations of the company with other natural persons and legal entities which are not within the scope ofconsolidation.

5. Periodical financial statements comprise all forms of incentives that is designed to grant shares to employees, i.e. employee stock ownership plans based on shares and/or other capital market instruments.

6. The annual report was signed by the board chairman, chief executive officer/general director and department manager responsible for the preparation of periodical financial statements and reports or by the company official who was appointed to fulfil such responsibility.

7. Financial information on a quarterly basis was explained.

8. An audit committee in charge of supervision of the financial and operational activities of the committee is established.

The below listed issues are incorporated in the company's annual report;

9. Scope of activities of the company,

10. Information about the sector in which the company operates and the company's status within this sector,

11. Board of directors' evaluation and analysis of financial status and operation results; level of achievement of the planned operations; the company's position with respect to the defined strategic objectives,

12. Board of directors' statement about the status of internal control system,

13. Audit firm's opinion about the internal control system,

14. Detailed explanation about the foreseeable risk factors regarding future operations,

15. Analysis of significant transactions carried out during the preceding year with the group companies and other related persons and institutions,

16. Changes in the organization, capital, ownership and management structure of the company,

17. Ownership structure table showing the controlling shareholder(s), as released from any indirect and cross ownership relation

18. Dividend policy; the reason/s for not distributing dividends, if applicable,

19. Future forecasts for sales, company's level of efficiency, company's market share, income yielding capacity of the company, company profitability and the company's debt/equity ratios and similar issues,

20. Statistical data and graphics about company and industry incorporated in the annual report.

21. The audit firm and auditors employed by such audit firm must be independent. (Independence principle indicates that the independent audit activities are conducted without being influenced by any relationship, benefit or other factors that may impede the auditor's professional discretion and impartiality. )

22. Name of the auditing firm is explained.

23. How much company pays in audit fees to the auditor is explained.

24. Audit firms are subject to regular rotation. (The board of directors appoint an audit firm for continuous and/or exclusive audits for a maximum period of 5 years. Capital Markets Board of Turkey.)

25. Audit and consultancy services are clearly separated.

26. All significant developments and their possible implications on the financial status and operational results of the company are disclosed immediately to the public. (e.g. uncertainty about the repayment of significant amounts of credit, a lawsuit brought against or filed by the company at significant amounts, any significant change in the management and capital structure of the parent company, any change in the company's major operations subsidiaries/affiliated companies and companies under joint management, any changes in or resignation of the company's audit firm or termination of independent audit agreement,

27. All Turkish Financial disclosure information is avaliable in English. 